\title{
Hubungan Antenatal Care terhadap Kejadian Stunting pada Balita Usia 0-24 Bulan di Wilayah Kerja Puskesmas Seberang Padang Tahun
}

\section{9}

\author{
Nurul Ramadhini ${ }^{1}$, Delmi Sulastri', Dolly Irfandy ${ }^{3}$ \\ ${ }^{1}$ Program Studi Profesi Dokter Fakultas Kedokteran Universitas Andalas, Padang \\ ${ }^{2}$ Bagian IImu Gizi Fakultas Kedokteran Universitas Andalas/RSUP Dr. M. Djamil Padang \\ ${ }^{3}$ Bagian Telinga Hidung Tenggorok Bedah Kepala Leher Fakultas Kedokteran Universitas Andalas Padang/RSUP Dr. M. Djamil \\ Padang
}

\section{A B S T R A C T}

\begin{abstract}
Latar Belakang. Stunting atau disebut juga dengan kerdil adalah keadaan dimana tinggi badan anak tidak sesuai dengan usianya dikarenakan kekurangan asupan gizi pada saat didalam kandungan dan awal kehidupan. Salah satu faktor yang mempengaruhi terjadinya stunting pada anak adalah riwayat antenatal care ibu selama hamil.
\end{abstract}

Objektif. Mengetahui hubungan antenatal care terhadap kejadian stunting pada balita berusia $0-24$ bulan di wilayah kerja Puskesmas Seberang Padang tahun 2019.

Metode. Penelitian ini merupakan penelitian analitik observasional dengan desain cross sectional pada 79 anak usia 0-24 bulan di wilayah kerja Puskesmas Seberang Padang yang dipilih melalui simple random sampling. Analisis data dilakukan dengan uji chi square.

Hasil. Penelitian dilakukan dengan wawancara dan observasi buku KIA serta hasil pengukuran panjang badan anak menggunakan infantometer. Prevalensi stunting (13,9\%), sebagian besar ibu memiliki kunjungan antenatal care lengkap $(19,4 \%)$ dan mendapatkan kualitas antenatal care yang baik $(15,8 \%)$. Nilai signifikansi kunjungan antenatal care 0,325 dan kualitas antenatal care 0,720 .

Simpulan. Antenatal care tidak berhubungan secara signifikan dengan kejadian stunting karena $p>0,05$.

Kata kunci: balita 0-24 bulan, kerdil, pemeriksaan rutin selama hamil, puskesmas.

Background. Stunting or also called dwarf is a condition where the height of the child does not match his age due to lack of nutritional intake at the time during pregnancies and early life. One of the factors that influence stunting in children is a history of maternal antenatal care during pregnancy.

Objective. To determine the relationship of antenatal care to the incidence of stunting in infants aged 0-24 months in the working area of Seberang Padang Primary Health Center Care in 2019.

Methods. This research was an observational analytic study with cross sectional design in 79 children aged 0-24 months in the working area of Seberang Padang Primary Health Care which was selected through simple random sampling. Data analysis was performed with the chi square test.

Results. The research was conducted by interviews and observations of maternal and child health books and the results of measurements of children's body length using an infantometer. The prevalence of stunting (13.9\%), most mothers have complete antenatal care visits (19.4\%) and get good quality antenatal care (15.8\%). The significance value of antenatal care visits is 0.325 and the quality of antenatal care is 0.720 .

Conclusion. Antenatal care is not significantly related to the incidence of stunting because of $p>0.05$.

Keywords : antenatal care, primary health care, toddlers 0-24 month, stunting.

Apa yang sudah diketahui tentang topik ini? Salah satu faktor yang mempengaruhi terjadinya stunting pada anak adalah riwayat antenatal care ibu selama hamil.

\section{Apa yang ditambahkan pada studi ini?}

Prevalensi stunting (13,9\%) pada wilayah kerja puskesmas Seberang Padang, sebagian besar ibu memiliki kunjungan antenatal care lengkap $(19,4 \%)$ dan mendapatkan kualitas antenatal care yang baik $(15,8 \%)$. Nilai signifikansi kunjungan antenatal care 0,325 dan kualitas antenatal care 0,720 . 


\section{Pendahulluan}

Indonesia saat ini sedang berada dalam ancaman terhadap generasi masa depan yaitu kegagalan pertumbuhan. Kegagalan pertumbuhan ini dimulai sejak 0-24 bulan atau lebih dikenal 1000 hari pertama kehidupan (HPK). Periode 1000 HPK ini adalah 270 hari didalam kandungan ibu dan 730 hari kehidupan pertama setelah anak lahir. Periode ini sangat berpengaruh terhadap kehidupan anak kedepannya baik dari segi pertumbuhan juga dari segi kognitif dan mental yang akan berdampak permanen terhadap anak, sehingga periode ini disebut sebagai Golden Period. Oleh karena itu, asupan gizi dan pola makan anak harus selalu diperhatikan. ${ }^{1}$

Menurut data World Health Organization 2017, situasi global stunting saat ini sudah mendunia. Di Asia terdapat $55 \%$ balita stunting dan di Afrika terdapat 39\% balita stunting. Diantara 5 bagian benua Asia, terbanyak di Asia Selatan yaitu 58,7\% dan paling sedikit di Asia Tengah yaitu 0,9\%. Berdasarkan data yang dikumpulkan WHO, Laos merupakan negara dengan persentase stunting tertinggi dan Indonesia adalah negara ketiga dengan prevalensi stunting tertinggi di regional Asia Tenggara. Laos memiliki rata- rata prevalensi balita stunting dari tahun 2015-2017 yaitu 43,8\% sementara Indonesia yaitu $36,4 \%$. Salah satu pulau dengan prevalensi anak pendek tertinggi yaitu pulau Nusa Tenggara khususnya provinsi Nusa Tenggara Barat, Kabupaten Lombok Utara dengan prevalensi anak pendek mencapai $44,22 \% .^{2}$

Stunting atau disebut juga dengan kerdil adalah keadaan dimana tinggi badan anak tidak sesuai dengan usianya dikarenakan kekurangan asupan gizi pada saat didalam kandungan dan awal kehidupan. Pada saat dilakukan pengukuran tinggi badan dan dimasukkan kedalam growth chart WHO 2006 TB/U didapatkan interprestasi kurang dari -2SD standar deviasi (Stunted) dan kurang dari -3SD (Severely Stunted). Kondisi kerdil ini dapat diketahui setelah usia anak 2 tahun dan sudah melewati 1000 HPK. Balita stunting termasuk dalam masalah gizi kronik yang sangat serius dan banyak dipengaruhi oleh berbagai faktor eksternal mulai dari sosial ekonomi, pendapatan keluarga, dan gizi ibu saat hamil. ${ }^{3}$

Kejadian stunting sangat dipengaruhi oleh berbagai faktor, salah satunya bagaimana pertumbuhan awal kehidupan anak didalam kandungan. Hal ini dapat dilihat dengan berapa kali kunjungan dan kualitas setiap kunjungan antenatal care (ANC). ANC merupakan suatu kegiatan kontrol rutin yang dilakukan oleh ibu hamil untuk melihat bagaimana kondisi janin dan kondisi fisik ibu yang bertujuan untuk mengetahui secara dini penyakit penyerta pada ibu dan janin sehingga dapat diantisipasi secepatnya. ${ }^{4}$

Pelayanan ANC ini didapatkan oleh semua ibu hamil, minimal melakukan 4 kali pelayanan sesuai pedoman pelayanan kesehatan ibu dan anak yaitu satu kali pada trimester pertama, satu kali pada trimester kedua dan dua kali pada trimester ketiga. Pelayanan ini bisa dilakukan bersama bidan atau dokter spesialis kandungan di fasilitas kesehatan yang sudah memiliki surat tanda register (STR) baik itu milik pemerintah atau swasta, dengan standar pemeriksaan yaitu $10 \mathrm{~T}$ diantaranya berat badan dan tinggi badan, tekanan darah, lingkar lengan (LiLa), tinggi fundus uteri, presentasi janin dan denyut jantung janin (DJJ), imunisasi tetanus toksoid (TT), tablet Fe, pemeriksaann laboratorium, konseling, tatalaksana atau mendapatkan pengobatan. Oleh karena itu, kunjungan ANC ini sangat berpengaruh terhadap pertumbuhan anak kedepan sehingga anak terhindar dari berat badan lahir rendah (BBLR), infeksi tokso/tetanus neonatorum, preeklampsia berat, kekurangan energi kronik (KEK), anemia defisiensi besi yang berujung pada stunting. 4

WHO telah memberikan batasan terendah terhadap setiap negara, provinsi, dan kabupaten pada masalah stunting yaitu sebesar $20 \%$. Dari target yang diberikan oleh WHO, Indonesia masih jauh dari target yaitu 36,4\%. Sementara berdasarkan Pemantauan Status Gizi (PSG) 2017, dari 34 provinsi di Indonesia hanya 2 provinsi yang melewati batas WHO yaitu Yogyakarta $(19,8 \%)$ dan Bali $(19,1 \%)$. Sementara provinsi lain masih dominan tinggi sekitar 30\% sampai 40\%. ${ }^{2}$ 
Menurut riset kesehatan dasar (RISKESDAS) 2018, telah dilakukan penelitian terhadap kunjungan ANC pada ibu hamil dan dilakukan perbandingan antara tahun 2013 dengan 2018, bahwa dari seluruh provinsi di Indonesia persentase kunjungan ANC terendah di Pulau Papua yaitu 71,7\%. Jika dibagi menurut pemeriksaan ANC pada kunjungan 1 (K1) dan kunjungan 4 (K4), persentase $\mathrm{K} 1$ terendah di provinsi Sulawesi Tenggara yaitu sebesar $67 \%$ pada tahun 2013 sedangkan pada tahun 2018 mengalami penurunan sebesar 3,5\%. Dan persentase $\mathrm{K} 4$ terendah di provinsi Papua yaitu sebesar 43,8\% pada tahun 2013 sementara tahun 2018 tidak terdapat data yang pastinya. ${ }^{5}$

Menurut data dari Dinas Kesehatan Sumatera Barat didapatkan persentase kunjungan ANC pada tahun 2017 mengalami penurunan dibanding 2015 yaitu pada tahun 2017, K1 sebesar 90,7\% dan K4 sebesar 79,9\% sementara tahun 2015, K1 sebesar 99\% dan K4 89\%. Ini memperlihatkan bahwa semakin bertambahnya tahun semakin besar kemungkinan menigkatnya angka kejadian stunting dimasyarakat. ${ }^{6}$ Jika dilihat dari hasil Riskesdas 2018, Sumatera Barat untuk kunjungan ANC urutan 15 dari 18 provinsi di Indonesia, yang masih dibawa target renstra 2018. Sedangkan angka kejadian stunting di Sumatera Barat urutan ke-13 dari 16 provinsi yang sudah diatas ratarata. $^{5}$

Data profil kesehatan Sumatera Barat tahun 2018, prevalensi stunting tertinggi terdapat di Kabupaten Pasaman yaitu sebesar 40,56\% sementara di Kota Padang prevalensi kejadian stunting $22,58 \%$. Jika dilihat dari laporan tahunan Dinas Kesehatan Kota (DKK) tahun 2018, Puskesmas Seberang Padang merupakan puskesmas yang paling rendah $\mathrm{K} 1$ dan K4 ANC dan tertinggi persentase stunting dibanding puskesmas lain. Untuk K1 sebesar 74,3\% sementara target pencapaian program $100 \%$ dan K4 sebesar 71\% sementara target pencapaian program $96 \%$ serta persentase stunting sebesar 23,04\%. Berdasarkan data di Puskesmas Seberang Padang, terdapat sebanyak 172 orang anak yang mengalami stunting. ${ }^{7}$

Berdasarkan data dan permasalahan diatas maka dari itu peneliti tertarik untuk meneliti mengenai Hubungan Antenatal Care terhadap Kejadian Stunting pada Balita 0-24 bulan di
Wilayah Kerja Puskesmas Seberang Padang tahun 2019.

\section{Metode}

Jenis penelitian ini adalah penelitian analitik observational dengan desain penelitian cross sectional. Variabel independennya adalah antenatal care pada responden dan variabel dependennya adalah kejadian stunting. Penelitian dilakukan dari bulan Agustus 2019-Maret 2020 di wilayah kerja Seberang Padang.

Populasi penelitian ini adalah seluruh baduta di wilayah kerja Puskesmas Seberang Padang yang berjumlah 304 orang. Sampel penelitian yang dipilih adalah bagian dari populasi yang memenuhi kriteria inklusi dan tidak memiliki kriteria eksklusi. Kriteria inklusi subjek: Ibu yang memiliki buku KIA dan anak usia 0-24 bulan yang stunting dan terdaftar di posyandu atau berdomisili di wilayah kerja Puskesmas Seberang Padang serta bersedia menjadi responden dalam penelitian ini. Kriteria eksklusi subjek: Responden yang tidak berada di rumah setelah tiga kali kunjungan.

Data diperoleh dengan cara wawancara dan observasi buku KIA serta pengukuran tinggi badan baduta dengan menggunakan infantometer. Data dianalisis secara statistik berdasarkan variabel yang dinilai menggunakan sistem komputerisasi yaitu analisis univariat dan bivariat. Analisis univariat dilakukan untuk melihat distribusi frekuensi dari masing-masing variabel independen dan variabel dependen. Analisis bivariat dilakukan untuk menganalisis hubungan antara variabel independen dan variabel dependen. Hubungan dua variabel tersebut dianalisis dengan menggunakan Fisher's Exact Test dan dikatakan tidak bermakna bila $\mathrm{p}>0.05$. Penelitian ini telah lulus kaji etik dengan nomor surat: 034/KEP/FK/2020.

\section{Hasil}

Penelitian ini dilakukan terhadap 87 baduta di wilayah kerja Puskesmas Seberang Padang pada tanggal 15 Januari - 3 Maret 2020. Selama periode tersebut jumlah responden yang memenuhi kriteria sebanyak 79 orang. 


\section{Karakteristik Responden}

Tabel 1. Distribusi Frekuensi Karakteristik Responden

\begin{tabular}{|c|c|c|}
\hline Karakteristik & $\mathbf{f}$ & $\%$ \\
\hline \multicolumn{3}{|l|}{ Jenis Kelamin } \\
\hline Laki-laki & 36 & 45,6 \\
\hline Perempuan & 43 & 54,4 \\
\hline \multicolumn{3}{|l|}{ Usia Baduta } \\
\hline $0-11$ bulan & 33 & 41,8 \\
\hline $12-24$ bulan & 46 & 58,2 \\
\hline \multicolumn{3}{|l|}{ Berat Badan Lahir } \\
\hline$<2500 \mathrm{gr}$ & 2 & 2,6 \\
\hline $2500-4000 \mathrm{gr}$ & 77 & 97,4 \\
\hline \multicolumn{3}{|l|}{ Panjang Badan Lahir } \\
\hline$<48 \mathrm{~cm}$ & 29 & 36,7 \\
\hline $48-52 \mathrm{~cm}$ & 50 & 63,3 \\
\hline \multicolumn{3}{|l|}{ Riwayat Penyakit Infeksi } \\
\hline Pernah terinfeksi & 2 & 2,5 \\
\hline Tidak pernah terinfeksi & 77 & 97,5 \\
\hline \multicolumn{3}{|l|}{ Usia Ibu Melahirkan } \\
\hline$<20$ tahun & 2 & 2,6 \\
\hline 20-35 tahun & 65 & 82,2 \\
\hline$>35$ tahun & 12 & 15,2 \\
\hline \multicolumn{3}{|l|}{ Penambahan Berat Badan } \\
\hline \multicolumn{3}{|l|}{ Ibu saat Hamil } \\
\hline$<10 \mathrm{~kg}$ & 37 & 46,8 \\
\hline $10-13 \mathrm{~kg}$ & 32 & 40,5 \\
\hline$>13 \mathrm{~kg}$ & 10 & 12,7 \\
\hline \multicolumn{3}{|l|}{ Tinggi Badan Ibu } \\
\hline$\leq 150 \mathrm{~cm}$ & 27 & 34,2 \\
\hline$>150 \mathrm{~cm}$ & 52 & 65,8 \\
\hline \multicolumn{3}{|l|}{ Riwayat PEB } \\
\hline Ada & 2 & 2,5 \\
\hline Tidak & 77 & 97,5 \\
\hline \multicolumn{3}{|l|}{ Pendidikan Ayah } \\
\hline Rendah & 15 & 19 \\
\hline Sedang & 52 & 65,8 \\
\hline Tinggi & 12 & 15,2 \\
\hline \multicolumn{3}{|l|}{ Pekerjaan Ayah } \\
\hline Tidak bekerja & 1 & 1,3 \\
\hline $\begin{array}{l}\text { Jasa(ojek/supir)/ buruh } \\
\text { bangunan }\end{array}$ & 32 & 40,5 \\
\hline PNS/TNI/Polri & 1 & 1,3 \\
\hline Pegawai swasta & 23 & 29,1 \\
\hline Pedagang/wiraswasta & 22 & 27,8 \\
\hline \multicolumn{3}{|l|}{ Pekerjaan Ibu } \\
\hline Tidak bekerja & 58 & 73,4 \\
\hline $\begin{array}{l}\text { Jasa(ojek/supir)/ buruh } \\
\text { bangunan }\end{array}$ & 1 & 1,3 \\
\hline PNS/TNI/Polri & 0 & 0 \\
\hline Pegawai swasta & 13 & 16,5 \\
\hline Pedagang/wiraswasta & 7 & 8,8 \\
\hline \multicolumn{3}{|l|}{ Pendapatan Keluarga } \\
\hline$<$ UMR & 36 & 45,5 \\
\hline$\geq$ UMR & 43 & 54,5 \\
\hline
\end{tabular}

Tabel 1 menunjukkan bahwa pada penelitian lebih dari separuh sampel berjenis kelamin perempuan
43 anak $(54,4 \%)$ dan sisanya berjenis kelamin laki-laki 36 anak $(45,6 \%)$ serta lebih separuhnya berusia $12-24$ bulan (58,2\%). Pada umumnya sampel lahir dengan berat badan lahir normal $(97,4 \%)$ dan lebih dari separuhnya sampel memiliki panjang lahir normal $(63,3 \%)$. Pada penelitian ini umumnya ibu sampel selama hamil tidak memiliki riwayat penyakit infeksi $(97,5 \%)$ dan sebagian besar ibu melahirkan di usia normal $(82,2 \%)$. Semua ibu sampel saat hamil mengalami penambahan berat badan paling banyak kurang dari $10 \mathrm{~kg}$ (46,8\%), lebih dari separuhnya memiliki tinggi badan lebih dari $150 \mathrm{~cm}(65,8 \%)$ dan sebagian besar ibu tidak memiliki riwayat penyakit preeklampsia (97,5\%). Ayah (51,9\%) dan ibu $(65,, 8 \%)$ sampel paling banyak memiliki tingkat pendidikan sedang. Pekerjaan ayah sampel paling banyak adalah jasa (ojek/supir)/buruh bangunan yaitu sebesar $40,5 \%$ sementara ibu sampel lebih dari separuhnya tidak bekerja $(73,4 \%)$. Lebih dari separuhnya sampel berasal dari keluarga yang memiliki pendapatan perbulan yang termasuk tinggi $(54,5 \%)$.

\section{Distribusi Stunting}

Pada penelitian ini didapatkan anak yang mengalami stunting lebih sedikit dibandingkan anak normal.

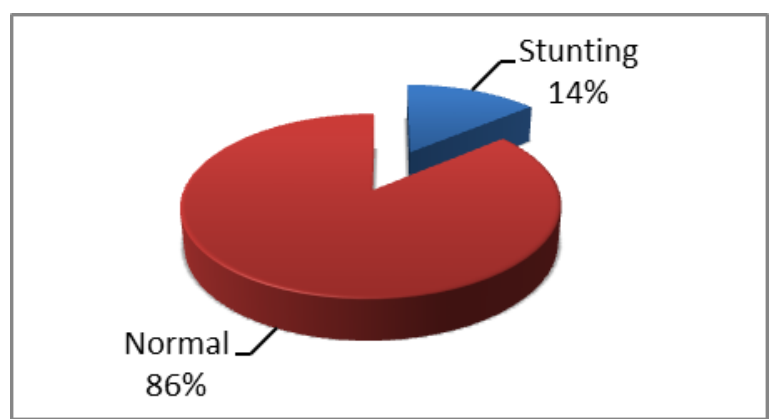

Gambar 1. Distribusi Frekuensi Kejadian Stunting

Pada penelitian ini menunjukkan bahwa terdapat sebanyak 13,9\% anak yang memiliki status gizi stunting.

\section{Distribusi Antenatal Care}

Pada penelitian ini didapatkan kunjungan antenatal care paling banyak adalah kunjungan tidak lengkap dan kualitas antenatal care yang paling banyak adalah tidak baik. 


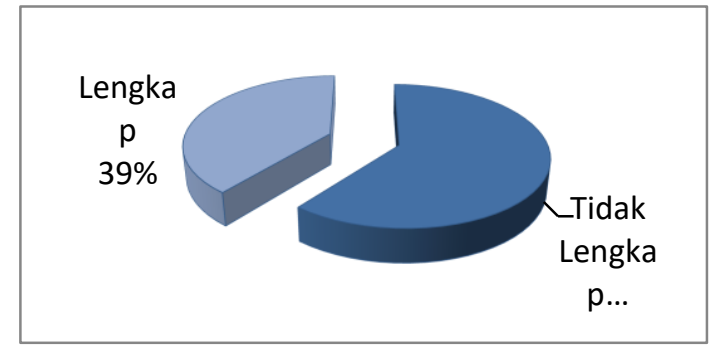

Gambar 2. Distribusi Frekuensi Kunjungan ANC

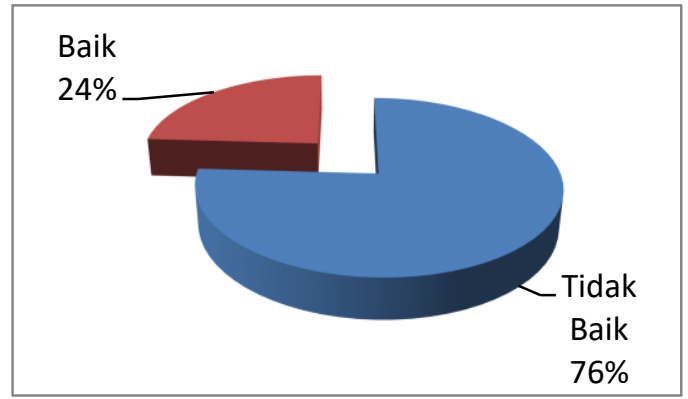

Gambar 3. Distribusi Frekuensi Kualitas ANC

Pada penelitian ini menunjukkan bahwa lebih dari separuh sampel memiliki riwayat antenatal care ibu selama hamil tidak sesuai dengan standar baik dari segi kunjungan $(60,8 \%)$ maupun kualitas (75,9\%).

\section{Hubungan Antenatal Care dengan Kejadian Stunting}

Tabel 2. Hubungan Antenatal Care Dengan Kejadian Stunting

\begin{tabular}{|c|c|c|c|c|c|c|c|c|}
\hline \multirow{3}{*}{ Variabel } & \multicolumn{4}{|c|}{ Kejadian Stunting } & \multirow{2}{*}{\multicolumn{2}{|c|}{ Total }} & \multirow{3}{*}{$\begin{array}{c}\text { OR } \\
(95 \% \mathrm{CI})\end{array}$} & \multirow{3}{*}{ p-value } \\
\hline & \multicolumn{2}{|c|}{ Stunting } & \multicolumn{2}{|c|}{ Normal } & & & & \\
\hline & f & $\%$ & f & $\%$ & $\mathbf{F}$ & $\%$ & & \\
\hline \multirow{2}{*}{\multicolumn{9}{|c|}{$\begin{array}{c}\text { Antenatal Care } \\
\text { Kunjungan }\end{array}$}} \\
\hline & & & & & & & & \\
\hline 1. Tidak lengkap & 5 & 10,4 & 43 & 89,6 & 48 & 100 & 0,48 & \multirow{3}{*}{0,325} \\
\hline 2. Lengkap & 6 & 19,4 & 25 & 80,6 & 31 & 100 & $(0,13-1,752)$ & \\
\hline Kualitas & & & & & & & & \\
\hline 1. Tidak baik & 8 & 13,3 & 52 & 86,7 & 60 & 100 & 0,82 & \multirow{2}{*}{0,720} \\
\hline 2. Baik & 3 & 15,8 & 16 & 84,2 & 19 & 100 & $(0,19-3,46)$ & \\
\hline
\end{tabular}

* Fisher's Exact Test

Pada tabel uji silang terdapat sel yang memiliki frekuensi harapan (expected count) kurang dari 5. Oleh karena itu, digunakan uji alternatif ChiSquare, yaitu Fisher's Exact Test.

Hasil uji statistik untuk kunjungan antenatal care diperoleh nilai $\mathrm{p}=0,325 \quad(\mathrm{p}>0,05)$. Berdasarkan hasil tersebut dapat disimpulkan secara statistik bahwa tidak terdapat hubungan yang bermakna antara kunjungan antenatal care dengan kejadiann stunting. Hasil uji statistik untuk kualitas antenatal care diperoleh nilai $p=0,720$ $(p>0,05)$. Berdasarkan hasil tersebut dapat disimpulkan secara statistik bahwa tidak terdapat hubungan yang bermakna antara kualitas antenatal care dengan kejadian stunting.

\section{Gambaran Faktor Risiko Stunting}

Stunting disebabkan oleh berbagai faktor risiko atau bersifat multifaktorial. Pada penelitian ini jika dilihat berdasarkan karakteristik responden ada beberapa faktor yang menyebabkan terjadinya stunting, diantaranya berat badan lahir, pendidikan ibu dan pendapatan keluarga. Dari hasil uji analisis menunjukkan bahwa proporsi anak yang stunting lebih banyak dengan anak yang memiliki berat badan lahir rendah $(50 \%)$ dibandingkan berat badan lahir normal (13\%). Sementara jika dilihat dari pendidikan ibu, proporsi anak stunting lebih banyak dengan ibu yang memiliki pendidikan rendah $(16,7 \%)$ setelah itu tingkat kedua pada ibu dengan pendidikan sedang $(14,8 \%)$ dan paling sedikit pada ibu pendidikan tinggi (8,3\%). Selanjutnya apabila dilihat dari pendapatan, pada penellitian ini bahwa kualitas ANC yang baik pada keluarga dengan pendapatan <UMR $(37,5 \%)$ lebih banyak proporsi anak yang stunting dibandingkan kualitas ANC yang baik dengan pendapatan $\geq U M R$ (0\%). Apabila kualitas ANC tidak baik dengan pendapatan keluarga <UMR (14,3\%) maka juga akan lebih banyak proporsi anak yang stunting dibandingkan dengan keluarga dengan pendapatan $\geq$ UMR $(12,5 \%)$.

\section{Pembahasan}

Stunting adalah kegagalan pertumbuhan (growth faltering) yang disebabkan karena ketidakcukupan nutrisi yang berlangsung lama, semenjak di dalam kandungan sampai usia 24 bulan (Hoffman et al, 2000; Bloem et al, 2013). ${ }^{41}$ Berdasarkan pengertian WHO stunting merupakan tinggi badan menurut umur $(\mathrm{TB} / \mathrm{U})$ berada dibawah -2 SD menurut median standar pertumbuhan anak WHO. Hasil penelitian univariat berdasarkan tabel 5.3 menunjukkan bahwa terdapat $13,9 \%$ anak usia $0-24$ bulan di wilayah kerja Puskesmas Seberang Padang memiliki status gizi stunting. Hasil ini jika dilihat dari batasan terendah yang telah ditentukan oleh WHO terhadap setiap negara, provinsi dan kabupaten tentang masalah stunting masih jauh dari ambang batas yaitu 20\% dan belum berisiko tinggi dikalangan masyarakat. Hasil penelitian ini juga lebih rendah dari pada penelitian yang 
dilakukan oleh Sentana dkk (2017) kepada 133 anak usia 12-24 bulan di Kelurahan Kampung Tengah Kecamatan Sukajadi Pekanbaru didapatkan 22,6\% anak yang memiliki status gizi stunting. ${ }^{42}$ Hasil yang tak jauh berbeda dilakukan oleh Sumiaty (2015) di Kota Palu terdapat 26,2\% anak usia 6-23 bulan yang mengalami stunting. ${ }^{43}$ Hasil penelitian lain juga dilakukan oleh Indrawati (2016) di Desa Karangrejek Gunung kidul pada anak usia 3-5 tahun didapatkan prevalensi stunting 26,9\%. ${ }^{8}$

Penelitian ini sebagian besar kejadian stunting terdapat pada kelompok umur $>12$ bulan. Rendahnya angka kejadian stunting pada penelitian ini dapat disebabkan oleh pendapatan keluarga. Pada penelitian ini pendapatan keluarga lebih dari separuhnya diatas rata-rata. Pendapatan keluarga berpengaruh besar terhadap gizi yang didapat oleh anak. Keluarga yang memiliki pendapatan lebih tinggi akan mudah dalam memenuhi kebutuhan makanan yang bergizi cukup dan beragam, sementara keluarga yang berpendapatan relatif rendah akan terbatas dalam membeli pangan seperti protein, vitamin, mineral yang dapat menyebabkan anak mengalami kekurangan gizi, baik zat mikro maupun mikro. Pendapatan yang minim dengan jumlah anggota keluarga yang bertambah tiap saatnya juga akan menentukan bagaimana ketersediaan pangan dalam keluarga. Apabila hal ini terjadi maka akan menyebabkan pengurangan pagan untuk setiap anak dan distribusi makanan menjadi tidak rata sehingga anak dapat mengalami kurang gizi. Sehingga semakin tinggi pendapatan keluarga maka semakin baik pula gizi anaknya. ${ }^{9}$

Antenatal care atau ANC adalah perawatan yang dilakukan atau diberikan kepada ibu hamil selama masa kehamilan. Asuhan perawatan ANC dilakukan minimal 4 kali selama kehamilan yaitu trimester I satu kali, trimester II satu kali, dan trimester III dua kali. Pada setiap pertemuan pemeriksaan yang dilakukan berdasarkan standar minimal pelayanan ANC yang diberikan kepada ibu hamil meliputi $7 \mathrm{~T}$ yang terdiri dari tinggi dan berat badan, tekanan darah, tinggi fundus uteri, imunisasi tetanus toksoid, pemberian tablet fe, tes laboratorium dan konseling. ${ }^{10,11}$

Pada penelitian ini didapatkan hasil bahwa anak usia 0-24 bulan lebih dari separuhnya memiliki ANC yang tidak lengkap sebesar 60,7\% dan 39,7\% ANC yang lengkap. Hasil yang tidak jauh berbeda didapatkan pada penelitian yang telah dilakukan oleh Evayanti (2014) di Puskesmas Wates Lampung Tengah dimana 55\% lebih banyak terdapat ANC yang tidak lengkap dibandingkan ANC yang lengkap sebesar $45 \% .{ }^{12}$ Sementara penelitian ini jauh berbeda dengan penelitian yang dilakukan Sumiaty (2017) pada anak usia 6-23 bulan di Kota Palu didapatkan 15,4\% ANC tidak lengkap dimana lebih rendah daripada ANC lengkap yaitu 84,6\%.13 Jika dilihat dari target Dinas Kesehatan Kota Padang mengenai ibu hamil mendapatkan pelayanan ANC, hasil penelitian ini masih jauh dari target tersebut yaitu $85 \%$ ibu hamil harus mendapatkan pelayanan ANC minimal empat kali. ${ }^{14}$

Perbedaan hasil ini kemungkinan dapat disebabkan oleh pendidikan ibu yang berbeda. Pada penelitian ini tingkat pendidikan ibu sebagian besar kategori rendah dan sedang. Sementara pada penelitian Sumiaty (2017) lebih separuhnya memiliki pendidikan tinggi. Pendidikan sangat mempengaruhi daya tangkap ibu dalam menyerap informasi yang didapatkan dari petugas kesehatan tentang antenatal care. Hal ini dapat kita lihat pada penelitian Evayanti dimana sebagian besar (83,3\%) ibu yang teratur melakukan ANC adalah ibu dengan pengetahuan yang baik yang berarti pendidikan ibu juga baik. Ibu yang memiliki pendidikan rendah akan sulit untuk memahami dengan baik apa yang disampaikan oleh petugas kesehatan, sehingga membuat ibu tidak memiliki pengetahuan yang cukup baik tentang ANC yang pada akhirnya mempengaruhi perilaku ibu untuk tidak teratur dalam melakukan kunjungan antenatal care. Semakin tinggi pendidikan ibu maka semakin luas pengetahuan ibu, hal ini akan berpengaruh kepada sikap ibu untuk melakukan kunjungan antenatal care dengan teratur. ${ }^{12}$

ANC terbagi atas kualitas dan kuantitas. Dimana kuantitas ANC yaitu berapa kali ibu melakukan kunjungan selama hamil Sementara kualitas ANC merupakan pemeriksaan apa yang sudah ibu lakukan selama melakukan kunjungan ke puskesmas. Jika dilihat dari kualitas ANC pada penelitian ini, terdapat sebagian besar berkualitas tidak baik yaitu $75,9 \%$ dan sisanya berkualitas baik sebesar 24,1\%. Sejalan dengan penelitian Najahah (2013) di Puskesmas Dasan Agung, Mataram, Provinsi Nusa Tenggara Barat bahwa

Nurul Ramadhini 
kualitas tidak baik $(52,5 \%)$ lebih banyak dari pada yang baiknya (47,5\%). ${ }^{15}$ Berbeda dengan penelitian Aulia (2016) di Lombok Utara dengan jumlah sampel 128 anak usia 12-59 bulan bahwa kualitas tidak baik lebih sedikit $(47,7 \%)$ dari yang baik $(52,3 \%){ }^{10}$

Perbedaan penelitian ini kemungkinan disebabkan oleh tempat pemeriksaan, alat pemeriksaan dan tenaga kesehatan ANC yang nantinya akan berpengaruh sangat besar terhadap kualitas ANC. Berdasarkan penelitian Dharmayanti dkk (2019) bahwa ANC yang ideal dipengaruhi oleh tenaga ANC dan tempat ANC. Pada penelitian Dharmayanti dari berbagai tenaga kesehatan yang ada seperti dokter kandungan, bidan, dokter umum dan perawat, didapatkan ANC ideal lebih tinggi proporsi pada bidan $(32,97 \%)$ dibandingkan yang lain. Sementara tempat ANC yang mendukung supaya didapatkan ANC yang ideal lebih banyak di poliklinik/ dokter/ bidan praktek. Tempat, alat dan tenaga kesehatan untuk melakukan pemeriksaan ANC sangat berhubungan satu sama lain. Tempat pemeriksaan berpengaruh terhadap kunjungan ANC ibu selama hamil apabila dekat dengan tempat tinggal akan lebih sering ibu melakukan kunjungan, sementara alat dan tenaga kesehatan akan berpengaruh terhadap kualitas ANC yang didapatkan ibu. Apabila alat pemeriksaan tidak sesuai standar maka akan didapatkan hasil yang bias dan penanganan yang diberikan tidak sesuai, maka dari itu hal ini perlu menjadi perhatian oleh tenaga kesehatan dimana tenaga kesehatan harus memiliki ilmu dan keahlian mengenai ANC. ${ }^{16}$

Berdasarkan hasil penelitian menggunakan Fisher's Exact menunjukkan tidak terdapat hubungan yang signifikan antara antenatal care dengan kejadian kejadian stunting dengan masingmasing nilai $\mathrm{p}$ untuk kunjungan antenatal care $=$ 0,325 dan nilai $\mathrm{p}$ untuk kualitas antenatal care $=$ $0,720(p>0,05)$. Penelitian ini menunjukkan baik itu kuantitas dan kualitas ANC tidak berhubungan dengan kejadian stunting, hal ini dapat disebabkan faktor lain yang mempengaruhi terjadinya stunting, diantaranya seperti berat badan lahir, pendapatan keluarga dan pendidikan ibu.

Pada penelitian ini meskipun ANC tidak berhubungan dengan kejadian stunting, namun terlihat proporsi anak stunting dengan berat badan lahir rendah lebih banyak (50\%) dibandingkan dengan berat badan lahir normal
(13\%). Jadi dapat disimpulkan bahwasannya berat badan lahir anak apabila rendah akan berisiko terjadinya stunting. Selanjutnya jika dilihat dari pendapatan pada penelitian ini, meskipun ibu sama-sama memiliki kualitas ANC yang baik tetapi tidak disertai dengan perekonomian atau status ekonomi yang melebihi UMR maka akan terlihat distribusi stunting itu lebih banyak pada ibu yang memiliki pendapatan yang kecil dari UMR yaitu 37,5\% dan ibu yang melebihi UMR 0\%. Apabila kualitas ANC ibu samasama tidak baik ditambah didukung oleh pendapatan dibawah UMR, tetap lebih tinggi kejadian stunting dari pada pendapatan diatas UMR. Menurut Adriani (2012) daya beli pangan suatu keluarga dipengaruhi oleh pendapatan keluarga tersebut. Dengan pendapatan yang tinggi akan dapat terpenuhinya kebutuhan makanan seluruh anggota keluarga. Namun, sebaliknya apabila pendapatan rendah maka tingkat daya beli akan ikut rendah sehingga menyebabkan tidak terpenuhinya kebutuhan gizi balita yang nantinya akan berpengaruh terhadap tumbuh kembangnya. ${ }^{17}$

Faktor lainnya yaitu pendidikan ibu, pada penelitian ini bahwa anak stunting paling banyak terdapat pada ibu dengan pendidikan rendah dan paling sedikit pada ibu dengan pendidikan tinggi. Pendidikan ibu berpengaruh pesat terhadap kehidupan anak kedepannya. Anak yang dibesarkan oleh keluarga yang memiliki pengetahuan tinggi akan berpengaruh terhadap pertumbuhan dan perkembangan tubuh anak. Orang tua yang memiliki pendidikan tinggi akan mudah menerima arahan dan informasi tentang gizi seimbang untuk anak dalam upaya peningkatan pertumbuhan dan perkembangan tubuh anak sehingga hasil yang didapatkan optimal. Tinggi rendahnya pendidikan seorang ibu sangat berpengaruh besar terhadap status gizi anak, gizi keluarga, perilaku hidup sehat, serta akses perawatan layanan kesehatan. ${ }^{9}$

\section{Simpulan}

Berdasarkan hasil penelitian ini didapatkan kesimpulan bahwa kejadian stunting pada balita usia 0-24 bulan di wilayah kerja Puskesmas Seberang Padang yaitu 13,9\% dengan riwayat antenatal care ibu responden paling banyak kunjungan tidak lengkap 60,8\% dan kualitas tidak baik $75,9 \%$. Hasil uji chi-square menunjukkan 
bahwa tidak terdapatnya hubungan yang signifikan antara antenatal care dengan kejadin stunting.

\section{Ucapan Terima Kasih}

Terima kasih penulis sampaikan kepada semua instansi yang telah membantu penyelesaian penilitian ini terutama Dinas Kesehatan Kota Padang, Provinsi Sumatera Barat.

\section{Daftar Pustaka}

1. Nurbaiti L, Adi AC, Devi SR, Harthana T. Kebiasaan makan balita stunting pada masyarakat suku sasak : Tinjauan 1000 hari pertama kehidupan (HPK). Masyarakat, Kebud dan Polit. 2014;27(2):109

2. Huang YW. Affecting factors of stunting incidences among children aged 12-59 months in West Nusa Tenggara Province Indonesia. J Healthc Commun. 2017;02(04):3-7

3. Windows M, Corporation M, Hori K, Sakajiri A. 1000 Kabupaten/Kota prioritas untuk intervensi anak kerdil (stunting). TNP2K. 2017;1-42

4. Pay AS, Klovning A, Sand S. Incidence/epidemiology national guidelines for antenatal care. NGF Obst Antenatal care Backe. 2014;7

5. Ministry of Health Republic of Indonesia. RISKESDAS 2018.

6. Dinas Kesehatan Provinsi Sumatra Barat. Profil Dinas Kesehatan Sumatera Barat Tahun 2017. 2017;67

7. Dinas Kesehatan Kota Padang. Laporan tahunan DKK Padang tahun 2018 Edisi 2019.

8. Indrawati S. Hubungan pemberian ASI esklusif dengan kejadian stunting pada anak usia 2-3 tahun di Desa Karangrejek Wonosari Gunungkidul . Universitas 'Aisyiyah Yogyakarta; 2016.

9. Permatasari DF, Sumarmi S. Perbedaan panjang badan lahir, riwayat penyakit infeksi dan perkembangan balita stunting dan non stunting. Jurnal Berkala Epidemiologi. 2018;6(2):182-91

10. Aulia A. Hubungan kunjungan antenatal care (ANC) dengan kejadian stunting pada balita usia 12-59 bulan di Kabupaten Lombok Utara Provinsi NTB tahun 2016. Fakultas Kedokteran Universitas 'Aisyiyah Yogyakarta; 2016.

11. Hendarwan H, Lestary H, Friskarini K, Hananto M. Kualitas pelayanan pemeriksaan antenatal oleh bidan di Puskesmas. Buletin Penelitian Kesehatan. 2018 Juni;2(46):97-108

12. Evayanti Y. Hubungan pengetahuan ibu dan dukungan suami pada ibu hamil terhadap keteraturan kunjungan antenatal care (ANC) di Puskesmas Wates Lampung Tengah Tahun 2014.

13. Sumiaty, S. Pengaruh faktor ibu dan pola menyusui terhadap stunting baduta 6-23 bulan. Jurnal Ilmiah Bidan. 2017;2(2):1-8

14. Direktorat Kesehatan Keluarga. Laporan akuntabilitas kerja tahun 2017. Padang:LAKIP;2017.

15. Najahah I, Adhi KT, Pinatih GI. Faktor risiko balita stunting usia 12-36 bulan di Puskesmas Dasan Agung, Mataram, Provinsi Nusatenggara Barat. Univ Udayana. 2013;38

16. Dharmayanti I, Azhar K, Hapsari D, Sari HP. Pelayanan pemeriksaan kehamilan berkualitas yang dimanfaatkan ibu hamil untuk persiapan persalinan di Indonesia. Jurnal Ekologi Kesehatan. 2019
Juni;1(18):60-69

17. Adriani, M dan Wirjatmadi, B. Pengantar gizi masyarakat. Kencana.Jakarta: 2012;48-57 